\section{Resistance to Blighting by Monilinia vaccinii-corymbosi in Diploid and Polyploid Vaccinium Species}

\author{
M.K. Ehlenfeldt ${ }^{1}$ and A.W. Stretch ${ }^{2}$ \\ U.S. Department of Agriculture, Agricultural Research Service, Philip E. \\ Marucci Center for Blueberry and Cranberry Research and Extension at \\ Rutgers University, 125A Lake Oswego Road, Chatsworth, NJ 08019
}

Additional index words. Vaccinium sp., mummy berry, blueberry, fungal disease, genetics

\begin{abstract}
Resistance to blighting by Monilinia vaccinii-corymbosi (Reade) Honey was evaluated under greenhouse conditions in multiple populations of the diploid species Vaccinium boreale Hall \& Aalders, V. corymbosum L., V. darrowi Camp, V. elliottii Chapm., V. myrtilloides Michx., V. myrtillus L., V.pallidum Ait., and V.tenellum Ait., as well as in accessions of the polyploid species $4 \times \mathrm{V}$. hirsutum Buckley and $6 x \mathrm{~V}$. corymbosum $\mathrm{f}$. amoenum Aiton. Significant species differences were found in mean blighting levels averaged over 2 years, with values ranging from $3.5 \%$ for $V$. boreale to $49.2 \%$ for $2 \times V$. corymbosum, compared with $27.5 \%$ for the resistant $4 x$ V. corymbosum check, 'Bluejay', and $64.3 \%$ for the susceptible $4 \times$ V corymbosum check, 'Blueray'. Wild Vaccinium species may serve as new sources of resistance to blighting, if resistance can be transferred easily and horticultural type recovered.
\end{abstract}

Mummy berry, caused by the fungus Monilinia vaccinii-corymbosi, is one of the most important fungal diseases of blueberry in North America because of its widespread occurrence and potential for reducing yield (Eck, 1988). The fungus overwinters on the soil surface as a pseudosclerotium (mummified fruit). In the spring, pseudosclerotia germinate to form apothecia that produce ascospores capable of inducing blight on newly emerging leaves, stems, and flower buds (Batra, 1983). The conidia subsequently produced on blighted tissue are carried by bees or wind to stigmas where they germinate, grow down the style into the ovary, and eventually produce a mummified fruit to complete the life cycle.

Resistance to mummy berry disease in highbush blueberry cultivars (Vaccinium corymbosum $\mathrm{L}$.) offers an alternative to chemical control, which is currently dependent on two fungicides, fenbuconazole $\{\alpha-[2-(4-$ chlorophenyl)ethyl]- $\alpha$-phenyl-1H-1,2,4triazole-1-propanenitrile $\}$ (Indar $\left.{ }^{\circledR}\right)$ (Rhone and Haas, Philadelphia) and propiconazole $\{1[2-$ (2,4-dichlorophenyl)-4propyl-1,3dioxolan-2yl]methyl]-1H-1,2,4-triazole $\} \quad\left(\right.$ Orbit $\left.^{\circledR}\right)$ (Sygenta, Greensboro, N.C.). Resistant cultivars could complement proven sanitary and cultural control practices (Eck, 1988), and eliminate or reduce fungicide use. Several studies have documented various levels of resistance to $M$. vaccinii-corymbosi in high-

\footnotetext{
Received for publication: 16 Dec. 1998. Accepted for publication: 20 Nov. 2000. The cost of publishing this paper was defrayed in part by the payment of page charges. Under postal regulations, this paper therefore must be hereby marked advertisement solely to indicate this fact.

${ }^{1}$ Research Geneticist. To whom requests for reprints should be addressed.E-mail address: mehlenfeldt@ ars.usda.gov

${ }^{2}$ Research Plant Pathologist.
}

bush blueberry cultivars (Nelson and Bittenbender, 1971; Pepin and Toms, 1969; Stretch et al., 1995; Varney and Stretch, 1966). In an evaluation of 52 highbush blueberry cultivars, Stretch et al. (1995) reported consistent blight resistance in several cultivars, including 'Jersey', 'Elliott', 'Bluejay', 'Duke', 'Stanley', and 'Darrow'. Across 48 cultivars, Ehlenfeldt et al. (1996) found a highly significant correlation $(r=0.74)$ between blight incidence and average shoot length during the first week of ascospore release. Shoot lengths of eight susceptible cultivars were $32 \%$ to $91 \%$ greater than the average for all cultivars during the first week. In contrast, shoot lengths for eight resistant cultivars were $18 \%$ to $42 \%$ shorter than the average for all cultivars. Ehlenfeldt et al. (1997) also demonstrated, that susceptibility within cultivars is a function of shoot length. As shoot length initially increases, more target tissue is offered to the pathogen and infection levels increase; however, as tissue continues to grow it toughens, and becomes more resistant. Nonetheless, most resistant cultivars showed comparatively higher levels of resistance across all shoot lengths, and some resistant cultivars, such as 'Stanley', exhibited relatively uniform resistance across all shoot lengths. The differences in susceptibility associated with shoot length suggested that some cultivars may derive a measure of resistance by disease avoidance (Burdon, 1987). Moreover, Lehman and Oudemans (1995, 1997a, 1997b) have recently demonstrated that populations of $M$. vacciniicorymbosi have distinct developmental phenologies and ascospore release periods that appear to correspond to the development of the host. Noncoincident phenologies between host and pathogen may account for low incidence of shoot blighting observed in some cultivars.
Less screening has been done for disease resistance in native Vaccinium species than in V. corymbosum. Galletta (1975) suggested, based upon empirical observations, that $V$. myrtilloides and $V$. uliginosum $\mathrm{L}$. were potential sources of resistance to Monilinia twig and blossom blight. In a natural field setting in New Jersey, Batra (1983) noted relatively low levels of fruit infection on $V$. myrsinites Lam. (2\%), V. myrtilloides (5\%), V. elliottii (1.5\%), and $V$. angustifolium Ait. (2.5\%), while infection on $V$. corymbosum hybrids averaged between $7 \%$ and $15 \%$. In greenhouse studies, Batra (1983) found neither blighting nor fruit infection on V. myrtillus, V. stamineum L., and V. macrocarpon Ait.

Stretch and coworkers (2000) screened diploid Vaccinium species and found superior resistance to fruit infection by $M$. vacciniicorymbosi in $V$. boreale, $V$. myrtilloides, $V$. pallidum, V. tennellum, and $V$. darrowi, but only moderate levels of resistance in $V$. elliottii and $2 \mathrm{x} V$. corymbosum. In this study, using many of the same populations, we evaluated resistance to the blighting stage of $M$. vacciniicorymbosi of 11 Vaccinium species, including resistant ('Bluejay') and susceptible ('Blueray') cultivars of $V$. corymbosum.

\section{Materials and Methods}

Plant material evaluated for resistance to blighting by $M$. vaccinii-corymbosi was selected from species collections housed at the Philip E. Marucci Center for Blueberry and Cranberry Research and Extension at Rutgers Univ., Chatsworth, N.J., and represented 29 different populations covering eight diploid blueberry species and two polyploid species. A number of these populations had been previously evaluated for other characteristics (Bruederle and Vorsa, 1994; Stretch et al., 2001). Five clones were selected to represent each population, except as noted. The species, accession, ploidy level, and origin are given in Table 1. On 6 Mar. 1997, plants in 3-L pots were moved into a greenhouse that was unheated, except as needed to maintain temperatures above freezing. Plants were placed on tables in a randomized complete-block design of five blocks, with each block being represented by a table. One plant each of the cultivars Blueray and Bluejay were included on each table as blight-susceptible and blightresistant controls, respectively. These plants were replaced once during the inoculation period to assess the continued availability of inoculum. Plants were arranged in a $4 \times 8$ grid pattern with $\approx 0.45 \mathrm{~m}$ between plants. Inoculum pots, each initially containing at least three to five apothecia, were placed within and around the grid so that a source of spores was within $0.3 \mathrm{~m}$ of each plant. The inoculum was produced from pseudosclerotia collected in late summer from various cultivars growing on the Rutgers Blueberry and Cranberry Research Station, and from several fields nearby. Pseudosclerotia were partially imbedded in the surface of moist, washed 1 sand : 1 peat moss (v/v) in 2-L pots, and kept in an unheated cold frame to receive necessary chilling. In the 
Table 1. Accession numbers and origins of Vaccinium species screened for resistance to shoot blighting by Monilinia vaccinii-corymbosi in 1997 and 1998.

\begin{tabular}{|c|c|c|}
\hline Species & Accession & Origin \\
\hline \multirow[t]{2}{*}{ V. boreale $2 \mathrm{x}$} & NJ 88-29 & Cape Breton Co., N.S., Canada \\
\hline & NJ $88-30$ & Cape Breton Co., N.S., Canada \\
\hline V. corymbosum $2 \mathrm{x}(2)^{\mathrm{z}}$ & NC 79-24b & Pender Co., N.C. \\
\hline \multirow[t]{4}{*}{ V. corymbosum $2 \mathrm{x}$} & NC 79-76a & Montgomery Co., N.C. \\
\hline & NC 79-76b & Montgomery Co., N.C. \\
\hline & NC 84-6b & Lake Co., Fla. \\
\hline & NJ $88-08$ & Santa Rosa Co., Fla. \\
\hline \multirow[t]{3}{*}{ V. darrowi $2 \mathrm{x}$} & NC 84-6a & Lake Co., Fla. \\
\hline & NJ 88-06 & Santa Rosa Co., Fla. \\
\hline & NJ $88-13$ & Liberty Co., Fla. \\
\hline \multirow[t]{2}{*}{ V. elliottii $2 \mathrm{x}(2)^{\mathrm{z}}$} & NC 83-1 & Richmond Co., N.C. \\
\hline & NJ $88-02$ & Evans Co., Ga. \\
\hline \multirow[t]{3}{*}{ V. elliottii $2 \mathrm{x}$} & NJ 88-01 & Bibb Co., Ga. \\
\hline & NJ 88-04 & Santa Rosa Co., Fla. \\
\hline & NJ $88-16$ & Stone Co., Miss. \\
\hline \multirow[t]{4}{*}{ V. corymbosum forma amoenum $6 \mathrm{x}$} & NJ 89-16 & Union Co., Ark. \\
\hline & NJ $89-17$ & Union Co., Ark. \\
\hline & NJ 89-18 & Ashley Co., Ark. \\
\hline & NJ 89-19 & Ashley Co., Ark. \\
\hline V. hirsutum $4 \mathrm{x}$ & NJ $90-54$ & Macon Co., N.C. \\
\hline \multirow[t]{3}{*}{ V. myrtilloides $2 \mathrm{x}$} & NJ $87-43$ & Washington Co., Me. \\
\hline & NJ $88-26$ & Chippewa Co., Mi. \\
\hline & NJ 88-27 & Bayfield Co., Wis. \\
\hline V. myrtillus $2 \mathrm{x}$ & --- & Austria \\
\hline \multirow[t]{3}{*}{ V. pallidum $2 \mathrm{x}$} & NC 79-5 & Montgomery Co., N.C. \\
\hline & NJ 89-12 & Yell Co., Ark. \\
\hline & NJ 91-2 & Barnstable Co., Mass. \\
\hline \multirow[t]{2}{*}{ V. tenellum $2 \mathrm{x}$} & NC 83-9 & Bladen Co., N.C. \\
\hline & NJ $88-31$ & Turner Co., Ga. \\
\hline \multirow[t]{2}{*}{ V. corymbosum $4 \mathrm{x}$} & Bluejay (resistant) & Michigan Agr. Expt. Station \\
\hline & Blueray (susceptible) & USDA-ARS \\
\hline
\end{tabular}

${ }^{\mathrm{z}}$ Values in parentheses indicate number of plants utilized if $<5$.

spring, prior to the start of the experiment, inoculation pots were moved to a heated greenhouse to hasten the development of apothecia. As apothecia started to develop, the pots were moved to the experimental block. Plants and inoculation pots were watered nightly with an automated sprinkling system that operated for $3 \mathrm{~min}$ every $3 \mathrm{~h}$ throughout the night. This assured that the foliage was kept wet during the night and early morning hours. Inoculum pots were checked weekly, and pots with senescing apothecia were replaced to assure continued availability of inoculum at very high levels.

Shoot lengths were measured once a week from 7 Mar. to 28 Apr. in 1997, and from 2 Mar. to 13 Apr. in 1998. Growth was evaluated by measuring five shoots per plant from bud base to leaf tip, and calculating the average shoot length for that plant. Measurements were discontinued when average shoot length for a plant reached $25 \mathrm{~mm}$ or when shoot blighting began to occur. Blighted shoots were removed and tallied weekly from the time shoot measurements ended until 16 May in 1997, and until 11 May in 1998, after which the remaining unblighted shoots were tallied.

The percentage of blight values were analyzed as a three-factor general linear mixed model using the Proc Mixed model of the Statistical Analysis System (SAS Institute, 1989), with species as the fixed factor, and year and block as random factors. The assumptions of the general linear model were tested. To correct variance heterogeneity, the species were grouped into similar variance groups for the analysis. Means were compared
Table 2. Mean shoot blighting by Monilinia vacciniicorymbosi on Vaccinium species in greenhouse studies across 1997 and 1998.

\begin{tabular}{|c|c|}
\hline$\underline{\text { Species }}$ & $\begin{array}{c}\text { Mean } \\
\text { blight } \%\end{array}$ \\
\hline V. boreale $2 \mathrm{x}$ & $3.5 \mathrm{a}$ \\
\hline V. myrtilloides $2 \mathrm{x}$ & $6.4 \mathrm{ab}$ \\
\hline V. myrtillus $2 \mathrm{x}$ & $11.9 \mathrm{a}-\mathrm{c}$ \\
\hline V. corymbosum f. amoenum $6 \mathrm{x}$ & $19.5 \mathrm{a}-\mathrm{d}$ \\
\hline V. tenellum $2 \mathrm{x}$ & $19.6 \mathrm{a}-$ \\
\hline V. darrowi $2 \mathrm{x}$ & $21.5 \mathrm{a}-\mathrm{d}$ \\
\hline V. elliottii $2 \mathrm{x}$ & $22.6 \mathrm{~b}-$ \\
\hline V. corymbosum $4 \mathrm{x}$ 'Bluejay' (resistant) & $27.5 \mathrm{~cd}$ \\
\hline V. hirsutum $4 \mathrm{x}$ & $43.6 \mathrm{de}$ \\
\hline V. corymbosum $2 \mathrm{x}$ & $49.2 \mathrm{e}$ \\
\hline V. pallidum $2 \mathrm{x}$ & $49.8 \mathrm{e}$ \\
\hline V. corymbosum $4 \mathrm{x}$ 'Blueray' (susceptible) & $64.3 \mathrm{e}$ \\
\hline
\end{tabular}

${ }^{\mathrm{z}}$ Means separated by a Sidák adjusted $\mathrm{p}$-value test, $P \leq 0.05$.

ferent from the four highest of these, $V$. myrtillus, 6x V.corymbosum forma amoenum, $V$. tenellum, and $V$. darrowi, nor from $V$. elliottii $(22.6 \%)$ or $V$. hirsutum $(43.6 \%)$. Blight values for 'Bluejay' were, however, significantly higher than those for both $V$. boreale and $V$. myrtilloides. A high-blight group with values ranging from $43.6 \%$ to $64.3 \%$ included $V$. hirsutum (43.6\%), 2x $V$. corymbosum $(49.2 \%)$, V. pallidum $(49.8 \%)$, and the susceptible $4 \times$ V. corymbosum check, 'Blueray' (64.3\%).

Although they could not be analyzed stausing a Sidák adjusted p-value procedure (Sokal and Rohlf, 1981), a highly conservative type of comparison for controlling experimentwise error rate. Statistical comparisons were not made within species because of variable numbers between several populations and the fact that plant mortality occasionally necessitated replacement of a clone within a population with another clone from that same population.

\section{Results and Discussion}

In 1997 and 1998, mean blight levels across all entries averaged $23.3 \%$ and $37.4 \%$, respectively. Greater shoot development was observed overall in 1998 than in 1997 (data not shown), and blighting increased for 25 of 30 $(83 \%)$ of the populations, but increased shoot development was not always associated with higher blighting levels. Across the 2 years, however, all populations had inoculum available during the growth phase associated with optimal susceptibility.

Significant differences were observed in blight levels among species $(\mathrm{F}=25.02, P \leq$ $0.0001)$ (Table 2). Statistical groupings with low blight values showed considerable overlap, while the highest blight group was relatively distinct, with only slight overlap with any other group. The lowest-blight group was comprised of six species, $V$. boreale $(3.5 \%), V$. myrtilloides (6.4\%), V. myrtillus (11.9\%), 6x V. corymbosum forma amoenum (19.5\%), $V$. tenellum $(19.6 \%)$, and $V$. darrowi $(21.5 \%)$. The resistant $4 \mathrm{x} V$. corymbosum check, 'Bluejay' (27.5\%) was not significantly diftistically because of the experimental design, some populations within species are worth noting (data not shown). In $2 \times 1$. corymbosum, population NC 79-24b appeared to be less susceptible to blight than were the other populations of $V$. corymbosum (12.9\% blight vs. a mean of $>47.0 \%$ for the four other populations); however, this population was represented by only two clones. This may simply represent a fortuitous selection of clones out of this population, or it may indicate that this population actually is more resistant to blighting as a whole. Among V. darrowi, population NC 84-6a had the lowest blighting value ( $7.1 \%$ blight vs. a mean of $>17.0 \%$ for the two other populations). Among V. elliottii, population NJ 88-04 had the lowest blight value across the 2 years ( $12.1 \%$ blight vs. a mean of $>19.0 \%$ for the four other populations). Although the $V$. pallidum populations also showed variability ( $34.9 \%$ to $64.7 \%$ ), the blighting values of all populations were sufficiently high that none would be of interest as sources of blight resistance.

In the study by Stretch and coworkers (2001), V. elliottii and V. corymbosum had low resistance to mummy berry fruit infection (i.e., secondary infection), while $V$. boreale, V. myrtilloides, $V$. pallidum, $V$. tenellum, and $V$. darrowi had moderate to high levels of resistance. In this study, $V$. boreale and $V$. myrtilloides also had superior resistance to the primary infection phase (shoot blighting) of mummy berry. Vaccinium boreale and V. myrtilloides are genetically similar based upon isozyme studies (Bruederle and Vorsa, 1994), and this similarity may 
extend to their response to the mummy berry pathogen. Of the remaining species common to the two mummy berry studies, $V$. elliottii and $V$. corymbosum were generally susceptible to both phases of the disease, whereas $V$. pallidum, $V$. tenellum, and $V$. darrowi were generally susceptible to the blighting phase, but not to the fruit infection phase. Bruederle and Vorsa (1994) found V. tenellum and $V$. darrowi to be similar by isozyme analysis. These two species also showed very similar responses to the mummy berry pathogen with moderate blighting (both $\approx 20 \%$ ), and zero to very low fruit infection in the study by Stretch et al. (2001).

Our findings agree with those of Galletta (1975), who regarded $V$. myrtilloides as a good potential source of blight resistance, but differ from those of Batra (1983) who found no blighting on V. myrtillus. Batra's V. myrtillus may have represented a more resistant selection of this species, or his cultural conditions may have rendered his plants less susceptible to blight infection at the time of inoculation.

This study represents only a small sample of the potential variation in mummy berry blight resistance available in Vaccinium species, but should serve as a guideline for species that may be good sources of resistance. At this moment, nothing is known regarding the inheritance of resistance from these different sources, although most of the species have been successfully hybridized with $V$. corymbosum, and introgressed germplasm of some species, such as $V$. darrowi, is available in quantity. These newly determined sources of blight resistance may prove valuable as primary or complementary sources of resistance if they can be successfully incorporated, and if a desirable horticultural type can be readily recovered.

\section{Literature Cited}

Batra, L.R. 1983. Monilinia vaccinii-corymbosi (Sclerotiniaceae): Its biology on blueberry and comparison with related species. Mycologia 75:131-152.

Bruederle, L.P. and N. Vorsa. 1994. Genetic differentiation of diploid blueberry, Vaccinium sect. Cyanococcus (Ericaceae). Systematic Bot. 19:337-349.

Burdon, J.J. 1987. Diseases and plant population biology. Cambridge Univ. Press, Cambridge, England.

Eck, P. 1988. Blueberry science. Rutgers Univ. Press, New Brunswick, N.J.

Ehlenfeldt, M.K., A.W. Stretch, and V. Brewster. 1996. Genetic and morphological factors affecting mummy berry blight resistance in highbush blueberry cultivars. HortScience 31:252-254.

Ehlenfeldt, M.K., A.W. Stretch, and J.S. Lehman. 1997. Shoot length affects susceptibility to mummy berry blight within highbush blueberry cultivars. HortScience 32:884-887.

Galletta, G.J. 1975. Blueberries and cranberries, p. 154-196. In: J. Janick and J.N. Moore (eds.).
Advances in fruit breeding. Purdue Univ. Press., West Lafayette, Ind.

Lehman, J.S. and P.V. Oudemans. 1995. Differences in rates of apothecium development between populations of Monilinia vacciniicorymbosi. Phytopathology 85:1133. (Abstr.)

Lehman, J.S. and P.V. Oudemans. 1997a. Phenology of apothecium production in populations of Monilinia vaccinii-corymbosi from early- and late-maturing blueberry cultivars. Phytopathology $87: 218-223$.

Lehman, J.S. and P.V. Oudemans. 1997b. Phenology of the mummy berry fungus and the blueberry host: Implications for resistance breeding. Acta Hort. 446:287-292.

Nelson, J. and H.C. Bittenbender. 1971. Mummy berry disease occurrence in a blueberry selection test planting. Plant Dis. Rptr. 55:651-653.

Pepin, H.S. and H.N.W. Toms. 1969. Susceptibility of highbush blueberry varieties to Monilinia vaccinii-corymbosi. Phytopathology 59:18761878.

Sokal, R.R. and F.J. Rohlf. 1981. Biometry, 2nd ed. W.H. Freeman and Co., New York.

Stretch, A.W., M.K. Ehlenfeldt, and V. Brewster. 1995. Mummy berry blight resistance in highbush blueberry cultivars. HortScience 30:589591.

Stretch, A.W., M.K. Ehlenfeldt, V. Brewster, N. Vorsa, and J. Polashock. 2001. Resistance of diploid Vaccinium species to the fruit rot stage of mummy berry disease. Plant Dis. 85:27-30.

Varney, E.H. and A.W. Stretch. 1966. Diseases and their control, p. 236-279. In: P. Eck and N.F. Childers (eds.). Blueberry culture. Rutgers Univ. Press, New Brunswick, N.J. 